\title{
THE DETERMINANTS OF HUMAN RESOURCE PRACTICES: AN EMPIRICAL INVESTIGATION IN THE TURKISH MANUFACTURING INDUSTRY
}

\author{
Assist.Prof.Dr.Hatice ÖZUTKU, Afyon Kocatepe University, Faculty of Economics \\ and Administrative Sciences, Department of Business Administration, \\ hozutku@aku.edu.tr \\ Assist.Prof.Dr.Harun ÖZTÜRKLER, Afyon Kocatepe University, Faculty of \\ Economics and Administrative Sciences, Department of Economics, \\ hozturkler@aku.edu.tr
}

\begin{abstract}
Human Resource Practice is a relatively new concept in Turkey. This paper documents the results of our empirical study on the determinants of human resource practices of 217 companies in the Turkish manufacturing industry. Therefore, this study aims at contributing to theory building by examining the determinants of human resource activities of recruiting and selection, training and development, compensation and benefits, performance appraisal, career development, and industrial relations empirically in the context of internal and external environments in which these activities take place. Our initial focus was on human resource activities of the firms considered, but the use of an empirical approach allowed also the inspection of the determinants of HR activities. This approach also assisted in identifying underlying relationships that could be interpreted as linkages among human resource activities and other organizational and environmental factors. It was possible to identify linkages between six major HR activities, and factors identified as internal, external, and control variables.
\end{abstract}

Key Words: Human Resource Practices, Turkish Manufacturing Industry

\section{INTRODUCTION}

A review of literature reveals that there has been an intense interest in last three decades in research on human resource (HR) practices. That drive for research has been fed by the use of different configurations of HR practices by companies (Gonzales and Tacoronte, 2006). At a theoretical level, many writers 
have suggested a number of competing explanations as to what determines HR practices (Miles and Snow, 1984; Tsui and Milkovich, 1987; Jackson et al., 1989; Milkovich and Bouderau, 1991). Organizations have many options when designing their HR practices (Jackson et al., 1989). However, there has been few explanatory research projects designed to identify the conditions that affect these choices. Empirical studies group the factors affecting HR practices as internal and external factors. Some of the factors such as international and national economic changes, technological changes, national culture/traditions, industry/sector characteristics, legislation/regulations, actions of competitors, and actions of unions that might affect the adoption of particular HR practices are taken as external to organizations, while the factors such as organization's size, organizational structure, business strategy, HR strategy, history, traditions and past practices, top management, line management, power and politics, and academic/professional influences are considered as internal to organizations.

This study aims at determining internal and external factors affecting HR practices in the Turkish manufacturing industry in the framework of the constituency perspective developed by Tsui and Milkovich (1987). We first review the existing conceptual bases of HR practices. Then, we conduct an empirical study in order to determine the factors affecting HR practices in the Turkish manufacturing firms.

\section{CONCEPTUAL BASES OF HUMAN RESOURCE PRACTICES}

Our survey of HR literature has suggested a number of competing theoretical explanations as to what determines HR practices. The main approaches can be categorized as follows: 1) institutional perspective (Meyer, 1980; Tolbert and Zucker, 1983), 2) political perspective (Pfeffer and Cohen, 1984; Osterman, 1987), 3) constituency theory perspective (Tsui and Milkovich, 1987; Crow, et al., 1995), 4) strategic human resource management perspective (Baird and Meshoulam, 1988; Delery and Doty, 1996), 5) behavioral perspective (Jackson et al.,1989), 6) management by competencies perspective (Spencer and Sepencer, 1993), 7) best practices perspective (Terpstra and Rozell, 1993; Pfeffer, 1994), and 8) management of intellectual capital perspective (Becker at al.,2001). In this study we follow the constituency perspective of Tsui and Milkovich (1987) because they analyze factors affecting HR practices in a comprehensive manner. They initially construct three separate theoretical perspectives: a) structural functionalism perspective, b) strategic constituency perspective, and c) strategic HR management perspective. They then offer a multiple constituency approach. In this study, following Tsui and Milkovich (1987)'s theoretical classifications, the different perspectives are first analyzed in order to determine HR practices suggested by each perspective and the determinants of these practices. This framework is then used to examine the determinants of HR practices in the Turkish manufacturing industry. 


\subsection{The Structural Functionalism Perspective}

Structural functionalism perspective emphasizes the importance of internal factors affecting HR practices. It has also been a major theoretical perspective used to account for the activities performed by the HR department (Tsui and Milkovich, 1987; Darmer, 2000). In this framework, the HR function is well suited to the strategic objective of the functional organization, which produces a limited line of products or services in as efficient way as possible (Miles and Snow, 1984). Thus, efficiency and cost effectiveness become the guiding philosophy in the management of HR for the attainment of organizational objectives (Miles and Snow, 1984; Gowler and Legge, 1986; Kamoche, 1991). Because of the focus on internal factors, the effects of external factors are not explicitly considered.

\subsection{The Strategic Contingency Perspective}

Strategic contingency theory highlights critical contingencies in the firm's external environment. The underlying assumption is that organizations have highly permeable boundaries, and HR practices respond directly to environmental demands. The buffering role of organizational strategy is not considered (Tsui and Milkovich, 1987). That is, HR practices are seen as a reaction to critical external pressures such as legal requirements and union activities (Jacoby, 1983; Kochan et al., 1984; Kane and Palmer, 1995). This perspective does not place any emphasis on internal factors in determining $\mathrm{HR}$ practices.

\subsection{The Strategic Human Resource Management Perspective}

In recent years, at both practical and theoretical levels, human resource management and strategic management have been integrated. This led to a new line of research denominated as strategic human resource management (SHRM). The idea is that human resource should be considered as a strategic factor, not only for its role in putting managerial strategy into effect, but also for its potential as a source of sustainable competitive advantage (Wang and Shyu, 2008).

SHRM involves designing and implementing a set of internally consistent policies and practices to ensure that firm human resources contribute to achieving business objectives (Chang and Huang, 2005). The basic premise underlying SHRM is that organizations adopting a particular strategy require HR practices that are different from those required by organizations adopting alternative strategies (Tichy et al., 1982; Miles and Snow, 1984; Dyer, 1984; Baird and Meshoulam, 1988; Peck, 1994; Sully et al., 1996; Delery and Doty, 1996; Grundy, 1997; Wright and Snell, 1998). 
Both internal and external environments are considered in light of the organization's mission and purpose. Once organizational strategies are determined, HR management strategy represents an integral part of achieving this broader organizational strategy (Kane and Palmer, 1995). Important HR practices common to much of the theoretical work in SHRM can be identified as; internal career opportunities, training, results oriented appraisals, profit sharing, employment security, and participation. By focusing principally on business strategies, the SHRM view systematically ignores other organizational contextual variables that may have important direct effects on HR department activities (Tsui and Milkovich, 1987).

\subsection{The Multiple Constituency Perspective}

All three views discussed above may be useful in examining the variety of activities performed by the HR department. Each view tends to emphasize a different set of determinants. However, economic and organizational contexts of HR practices are more complex and dynamic than those depicted by any of the three perspectives individually.

The multiple constituency approach treats HR department as the unit of analysis and defines environment in terms of the plurality and complexity of constituencies' expectations (Tsui and Milkovich, 1987). Constituents may include both insiders and outsiders and may be defined as any individual, groups of individuals, or organization with a special stake or claim against an organization.

According to Tsui and Milkovich (1987), the HR department must engage in strategic transactions with its constituencies. This is because its ultimate survival will depend on its ability to meet stakeholders' expectations or demands. Therefore, in contrast to the other perspectives, according to this perspective, HR practices are influenced by both internal and external factors. Furthermore, types of factors and their relative importance will vary with the country and sector where the firms operate, sizes of the firms, and nature of the technology used in the production process.

\section{DETERMINANTS OF HR PRACTICES}

External and internal factors affecting HR practices differ significantly across countries. Indeed, within both national and organizational contexts there exists extensive diversity in HR practices. The differences in practices are linked to environmental and organizational characteristics including size of firm, industrial sector, type of economic activity, managerial ideology, national culture, business strategy, organizational structure, and age of organization (Poole and Jenkins, 1997). The diversity of practices is reflected in the wide range of models of HR and the changing influences of different factors on HR practices 
(Jackson et al., 1989). Some of the major potential influences are summarized below.

\subsection{External Factors}

The market environment has been extremely turbulent during the past decade. Therefore, to maintain continuous success in the face of rapidly changing global conditions, firms must identify and analyze environmental characteristics and develop HR practices to meet changing market needs (Chang and Huang, 2005). External factors affecting HR practices are those pressures on firms that cannot be controlled and changed in a favorable way in the short run (Kane and Palmer, 1995). External factors are briefly explained below.

International and national economic changes: With the development of global economy, the international dimension of HR practices has become more and more significant. The focus of HR practices has shifted from traditional topics such as internal selection and rewards to concepts such as globalization and international competition (Satow and Wang, 1994).

Technological changes: Technology lies at the heart of manufacturing industry. It provides a series of business advantages (Garavan et al., 2008). As organizations have been faced with shrinking product life cycles in many industries, in many cases, they have started re-assessing their operational arrangements and managing processes (Power, 2004). This is because of the fact that technological advances alter jobs, create new skills, make occupations obsolete, and revise what employees need to learn and be trained to do (Milkovich and Boudreau, 1991; Watson and Green, 1996; Wong, 1997). In addition, technological developments alter the context of HR practices and the way they are implemented.

National culture: The increasing internationalization and globalization of business makes it more pressing than ever to understand how to establish HRM practices that can deal with cultural and national differences (Alas et al., 2008). Culture has a crucial importance in organizations' preferences in developing appropriate structure and methods for their HR practices (Chandrakumara and Sparrow, 2004). Cultural factors cover a wide range of issues and differ significantly across countries (Yeganeh and Su, 2008). Wasti (1998) investigates the applicability of Japanese and American human resource practices in Turkey from a socio-cultural perspective. By comparing workrelated values of the three countries, she emphasizes the contextual differences between developing and industrialized countries. She argues that Japanese HR practices are more compatible with Turkish societal characteristics than are their American or Western counterparts. On the other hand, intra-national differences existing in the same country also lead to variations in HR practices. For instance, Kozan (1999) points out that in Turkey a systematic, two-century- 
long attempt to transform a traditional society has created a heterogeneous culture with major differences in values among various segments.

Industry/sector characteristics: In analyzing HR practices, classification of organizations as manufacturing and service firms is taken as the basis of the discussion. The idea behind this division is the fact that different production processes necessitate different HR practices.

Legislation/regulations: Legislation and regulations are frequently cited as having a direct impact on HR practices (Kane and Palmer, 1995). In Turkey, the constitution sets the basic rules regarding the operations and functions of organizations.

Actions of competitors: Differences in HR practices are likely to be found when comparing organizations that differ in the extent to which they are attempting to gain competitive advantage. There are many ways in which companies can gain a competitive edge or a lasting and sustained advantage over their competitors, among them being the development of comprehensive human resource practices (Jackson et al., 1989; Kane and Palmer, 1995; Poole and Jenkins, 1996; Narasimha, 2000).

Actions of unions: In order to analyze the factors affecting the HR practices, one also needs to consider the activities of unions. Some unions may seek to influence HR practices more directly than others. The presence or absence of unions in organizations is a salient variable known to be associated with some HR practices (Kochan et al., 1984). There are noticeable changes in industrial relations towards more employee-oriented relations. The question here is how to find room for the coexistence of HRM and industrial relations practices. This is crucial for finding a reasonable balance between the practices of collective bargaining and concrete employee centered employment relations (Alas et al., 2008).

\subsection{Internal Factors}

Internal environments of organizations strongly affect their HR practices. Internal factors specific to a firm influence its response to a given situation. The effect of a firm-specific variable upon HR practices will depend on the situation facing the firm at a given decision point. That is, one variable dominant at one stage may be substituted by another as circumstances change (Welch, 1994). Researchers have compiled a lengthy list of organizational characteristics related to HR practices (Milkovich and Boudreau, 1991). Internal factors included in the present study are briefly explained below.

Organization's size: Organization's size is an important factor explaining both the intensity and the type of HR practices (Garavan et al., 2008). Although HRM practices are a common feature within organizations, evidence suggests that there are a large number of small firms that do not practice them (McPherson, 
2008). HR practices in a sense are a result of growth and functional divisions. While one or two employees are enough for conducting HR practices in small size organizations, in large organizations, for each functional level there may be a need for a different HR department (Jackson et al., 1989; Kaynak, et al., 1998). Moreover, one of key areas of differences between small and large firms is in terms of organizational culture. This can affect a variety of HR practices, such as training, and reward systems (Ghobadian and Gallear, 1997).

Organizationalstructure: In response to global competition and a rapidly changing business environment, corporate strategies and structure are becoming more flexible and integrated. A firm' strategy and structure are important in determining HR practices flexibility and integration. There are important structural differences among firms that affect the way in which HR practices are designed and implemented (Garwin, 1986; Tomer, 1995; Hudson, et al., 2001).

Business strategy: There is a two-way causality between business strategy and human resource decisions. Organizations generally use different competitive strategies in order to gain an advantage in the marketplace. These strategies are most effective when they are systematically coordinated with human resource management practices. Companies can improve their environment by making efficient choices about human resource practices that consistently support their chosen strategy (Milkovich and Boudreau, 1991; Schuler, 1992).

Human resource strategy: HR strategy is an important determinant of both intensity and diversity of HR practices (Garavan et al., 2008). HR strategy's purpose is to help guide managers' HR practices and thereby affect the success of the organization. The HR strategy of an organization refers to its fundamental approach toward its employees (Lengnick-Hall and Lengnick-Hall, 1988; Milkovich and Boureau, 1991). As a rule, HR practices are shaped in accordance with HR strategy.

History, traditions, and past practices: Resistance to change is an essential factor to be considered in any change process. Resistance is any conduct that tries to keep the status quo, A number of closely related factors, such as history, traditions and past practices tend to generate resistance to change in most organizations (Kane and Palmer, 1995; Pardo and Fuentes, 2003).

Top management: The influence of top management on HR practices is acknowledged by most writers, even if only to the extent of advising that top management's support should be obtained (Ondrack and Nininger, 1984; Kane and Palmer, 1995). The management style, priorities, and practices within the organization significantly influence HR practices (Garavan et al., 2008).

Line management: A key to organizational success is the active participation of line management in designing and implementing HR activities. Since line managers are responsible for creating value, they should integrate HR practices 
in their work (Okpara and Wynn, 2008; Alas et al., 2008). This requires a dynamic power and information sharing relationship between HR department and line managers (Gautam and Davis, 2007).There are four fundamental observations regarding the responsibilities of line management (Poole and Jenkins, 1997). First, line management has a considerable responsibility for HR practices. Second, the responsibility of line management changes over time. Third, line management has assumed a greater responsibility for HR issues with the rise of strategic HR management. Finally, organizations differ in terms of the responsibility of line management for HR practices.

Power and politics: The influence of power and politics is noted frequently, especially when considering why new policies and procedures are not implemented. Whether internal or external, the HR manager is faced with the task of identifying which of the array of stakeholders confronting the organization are the critical constituents of the HR practices. The key is identifying all of them and accurately determining their source of power.

Power and politics as exercised by various constituencies are crucial determinants of HR practices (Tsui and Milkovich, 1987). HR manager has the task of identifying which of stakeholders are the critical constituents of the HR practices (Crow et al., 1995; Kane and Palmer, 1995).

Academic/professional influences on HR practice: HR staff are often involved in the decision making process about HR policies and practices. Their knowledge about alternative HR practices may represent important variables in their own right (Kane and Palmer, 1995). Potential inputs to these knowledge bases include the written body of HR theory and research, what they have learned from experience, and information obtained from peers, particularly those working in the same industry. Another source of knowledge for HR is consulting firms.

Having examining the external and internal factors affecting HR practices, we can argue that the effects of these factors are not same in terms of both the extend of the effects and the channels through which the factors exert their effects. For instance, economic factors will affect wage determination and recruitment of new employees more than it will affect other aspects of HR practices. In order to determine which factor has more effect than other factors on HR practices we have conducted an empirical analysis on the Turkish manufacturing industry. In the empirical work below, we have aimed at determining dominant factors in terms of both general HR practices and sub practices individually. 


\section{METHODOLOGY}

\subsection{The Model}

On the basis of the above analysis we construct a simple model shown in Figure 1. In the model, HR practices in the Turkish manufacturing industry are taken as a function of external, internal, and control variables. Figure 1 depicts this functional relationship in a diagrammatic form. External and internal variables included in the research model are selected following Kane and Palmer (1995). Several control variables are also included in the model. First control variable is firms' market orientations. Market orientation affects characteristics of employment, and therefore HR practices. A measure of organizational size is included in the model because size of a firm is considered to be correlated with some HR practices (Jackson et al., 1989). Other possible control variables are existence of total quality management (TQM), organizational mission, and an overall HR strategy. Finally, the model takes the practices regarding recruitment and selection, training and development, compensation and benefits, performance appraisal, career development, and industrial relations as the HR practices.

Figure 1: Determinants of HR Practices

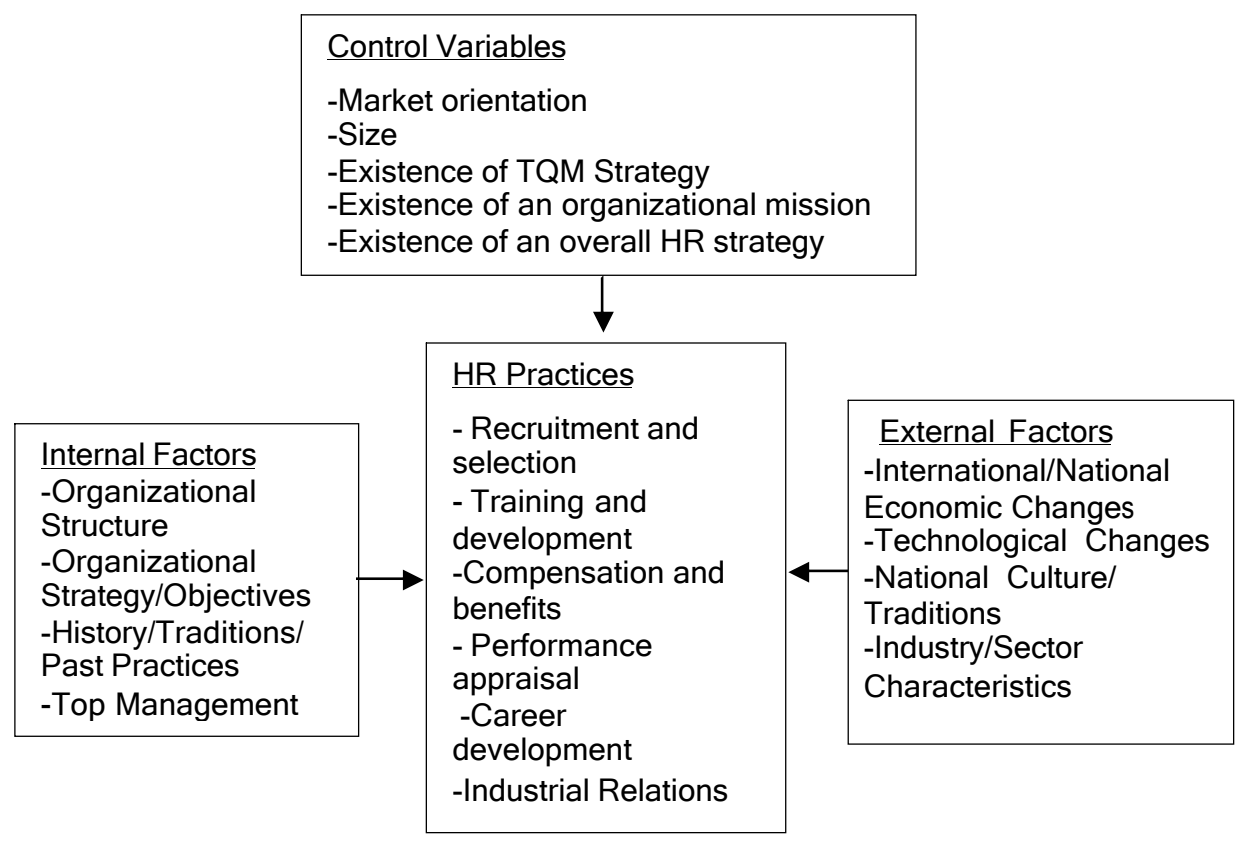




\subsection{Research Questions}

Research questions have been derived from a review of the existing literature, which identified six major areas of HR practices- recruiting and selection, training and development, compensation and benefits, performance appraisal, career development, and industrial relations- as being important for organizations' success. The research questions are:

(1) Which factors are the most effective in the HR practices in the Turkish manufacturing industry?

(2) Do the factors affecting HR practices vary according to;
a) market orientation (national-international) of the firm?
b) size of the firm?
c) existence/non existence of a TQM strategy?
d) existence/non existence of an organizational mission?
e) existence/non existence of an HR strategy?

\subsection{Choice of Industry}

The Turkish economy can be grouped into a large number of industrial sectors, but the distinction between manufacturing based and service-based industries is one of the basic classifications. The manufacturing industry was selected for several reasons. First, we chose a single industry to control for between industry differences. Second, the firm size varies significantly in the manufacturing industry. Third, while some firms produce a wide variety of products to a diverse set of customers, others produce a limited line of products to a largely homogeneous set of customers. Finally, in manufacturing industry HR practices show a great level of heterogeneity.

\subsection{Data Collection and Sample}

We have conducted a survey. The survey questions have been grouped into four parts. The first group questions were on information about the firm. The second group included questions about the HR department. The third group questions aimed at determining factors affecting HR practices. Finally, the fourth group questions aimed at evaluating each factor from the perspective of individual HR practice. The third and fourth group questions have been prepared according to Likert Scale.

We selected an initial stratified random sample of 300 manufacturing firms using the following procedure. The exact number of the firms operating in the Turkish manufacturing industry is not known. Therefore, we have determined the regions of Turkey where manufacturing industry firms cluster. Then, conducted face to face interviews during the spring of 2007 with the HR managers of the 300 hundred firms using a questionnaire. 217 of the managers 
answered the questionnaire. Since the KMO value is 0.882 , we can conclude that we have a satisfactory level of sampling adequacy.

\subsection{Results}

The survey results show that $42.4 \%$ of the firms is national market, $43.3 \%$ is international market, and $14.3 \%$ is both national and international market oriented firms. In terms of the years of experience, $31.3 \%$ of the firms is $1-9$ years, $47.5 \%$ is $10-29$ years, and $21.2 \%$ is $30+$ years old firms. We define firms that employ 0-49 people as small sized, 50-249 people as medium sized, and $250+$ as large sized firms. On the basis of this definition, $34.6 \%$ of the firms are small sized, $45.7 \%$ is medium sized, and $19.7 \%$ is large sized firms. $49.4 \%$ of the firms employ TQM for $1-3$ years, $27.5 \%$ for $4-6$ years, $6.9 \%$ for $7-9$ years, and $8.9 \%$ for $10+$ years. Finally, $51.9 \%$ of the firms have a written organizational mission and $36.1 \%$ has a written overall HR strategy.

Table 1 and Table 2 present the means, standard deviations, and correlations among the responses to the various possible influences on HR practices. The scale ranges from $1=$ no impact through $5=$ great impact. We assume influences with mean score of 3.0 or above as representing relatively major influences.

The correlations in Table 1 and Table 2 point to a range of significant relationships among external variables, internal variables, and control variables. Assuming that 0.5 and above correlation score is significant, we can make the following list of correlations.

Above correlations reveal that $\mathrm{HR}$ theory/research and education/training in $\mathrm{HR}$ are two important variables that affect each other and overall HR strategy. This result indicates that HR managers in the Turkish manufacturing industry follow the developments in HRM theory and put those developments in formulating their organizations' HR strategies. 
Hatice ÖZUTKU ve Harun ÖZTÜRKLER

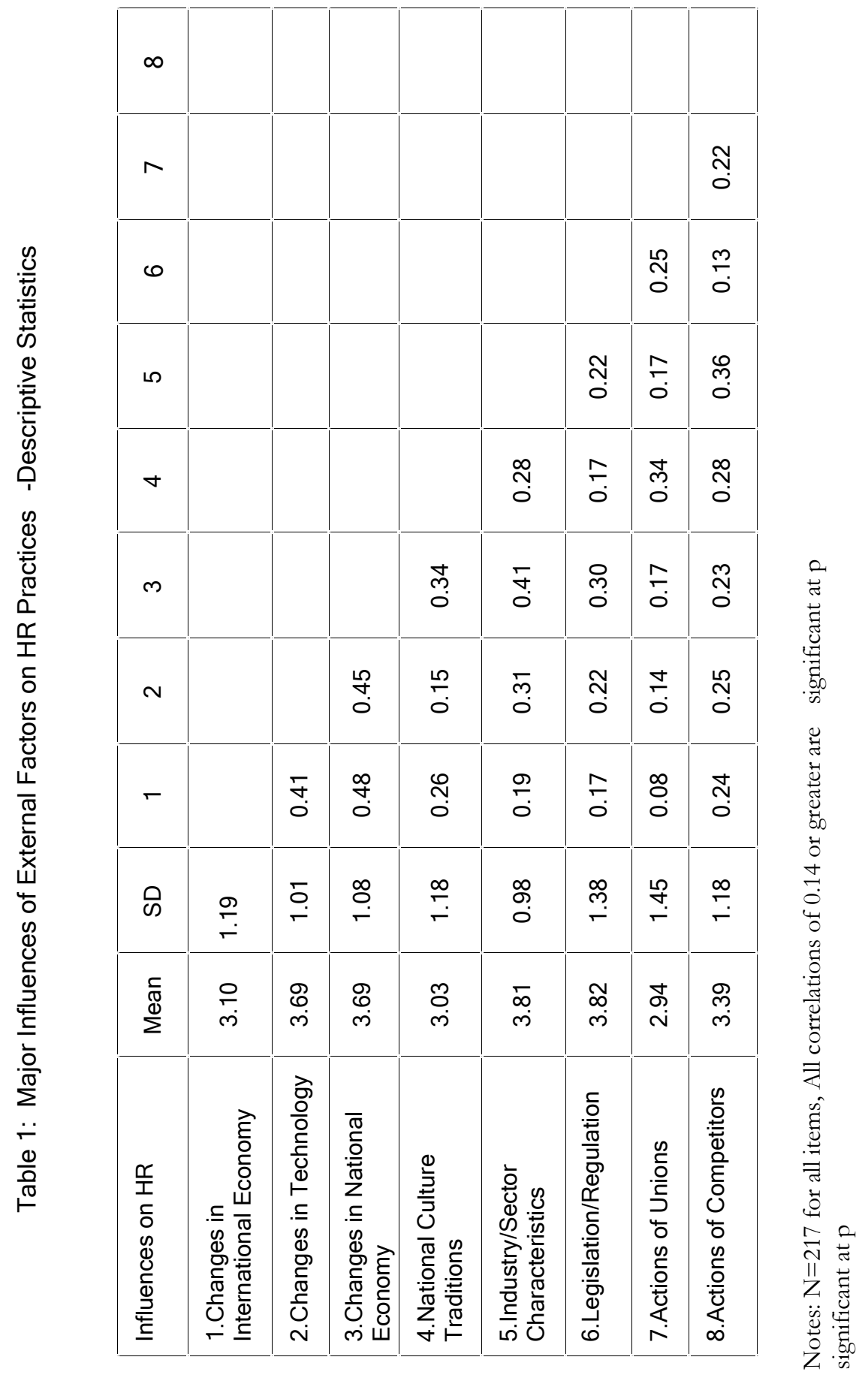


THE DETERMINANTS OF HUMAN RESOURCE PRACTICES: AN EMPIRICAL INVESTIGATION IN THE TURKISH MANUFACTURING INDUSTRY

Table 2: Major Influences of Internal Factors on HR Practices-Descriptive Statistics

\begin{tabular}{|c|c|c|c|c|c|c|c|c|c|c|c|c|c|c|c|c|}
\hline Influences on HR & Means & SD & 9 & 10 & 11 & 12 & 13 & 14 & 15 & 16 & 17 & 18 & 19 & 20 & 21 & 22 \\
\hline $\begin{array}{l}\text { 9. Organizational } \\
\text { Mission/Purpose }\end{array}$ & مُ & $\stackrel{\mathscr{N}}{\stackrel{-}{-}}$ & & & & & & & & & & & & & & \\
\hline $\begin{array}{l}\text { 10.Organizational } \\
\text { Strategy/Objectives }\end{array}$ & $\begin{array}{l}\mathbb{\infty} \\
\dot{m}\end{array}$ & $\stackrel{r}{\stackrel{r}{r}}$ & @̈ & & & & & & & & & & & & & \\
\hline $\begin{array}{l}\text { 11.Actions of Corporate } \\
\text { Headquarters }\end{array}$ & $\begin{array}{l}\hat{N} \\
m\end{array}$ & $\stackrel{8}{\mathscr{\ell}}$ & $\stackrel{?}{+}$ & 呬 & & & & & & & & & & & & \\
\hline $\begin{array}{l}\text { 12.Size of the } \\
\text { Organization }\end{array}$ & $\underset{\Gamma}{\bar{N}}$ & $\stackrel{8}{\mathscr{8}}$ & $\stackrel{\text { ? }}{\stackrel{0}{0}}$ & 点 & ช్ & & & & & & & & & & & \\
\hline $\begin{array}{l}\text { 13. Structure of the } \\
\text { Organization }\end{array}$ & ஜே & $\stackrel{m}{0}$ & $\stackrel{\text { L }}{+}$ & 常 & 守 & $\begin{array}{l}\text { Jै } \\
\stackrel{0}{0}\end{array}$ & & & & & & & & & & \\
\hline $\begin{array}{l}\text { 14. History/Traditions/Pa } \\
\text { st Practices }\end{array}$ & 艿 & $\stackrel{m}{\leftarrow}$ & $\stackrel{\text { mొ }}{\circ}$ & $\stackrel{\text { Yे }}{0}$ & ঙ্লি & 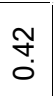 & $\begin{array}{l}\infty \\
\stackrel{\infty}{n} \\
0\end{array}$ & & & & & & & & & \\
\hline $\begin{array}{l}\text { 15.Priorities of Top } \\
\text { Management }\end{array}$ & $\begin{array}{l}\hat{\infty} \\
\infty \\
\end{array}$ & क़े & స̃ & 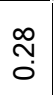 & $\stackrel{\mathscr{m}}{0}$ & $\widetilde{m}$ & $\stackrel{\substack{N \\
o}}{n}$ & $\stackrel{\stackrel{L}{N}}{0}$ & & & & & & & & \\
\hline $\begin{array}{l}\text { 16.Priorities of Line } \\
\text { Management }\end{array}$ & 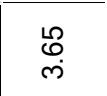 & б. & $\stackrel{10}{\frac{0}{0}}$ & స় & $\hat{m}$ & $\stackrel{\text { N̦ }}{0}$ & 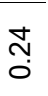 & $\stackrel{\bar{N}}{0}$ & 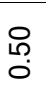 & & & & & & & \\
\hline $\begin{array}{l}\text { 17.Issues of Power and } \\
\text { Politics }\end{array}$ & 占 & $\stackrel{\circ}{\circ}$ & సุ & $\stackrel{\text { m}}{\circ}$ & $\stackrel{\circ}{+}$ & 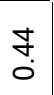 & ¿্் & $\stackrel{\infty}{\sim}$ & $\hat{m}$ & 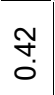 & & & & & & \\
\hline $\begin{array}{l}\text { 18.Impact of HR Theory/ } \\
\text { Research }\end{array}$ & $\stackrel{\oplus}{m}$ & $\stackrel{\infty}{\leftarrow}$ & 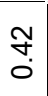 & ঙे & ָ̃ & ले & 里 & $\underset{N}{0}$ & $\frac{9}{\circ}$ & $\stackrel{\widetilde{m}}{\circ}$ & 古 & & & & & \\
\hline $\begin{array}{l}\text { 19.Impact of Education/ } \\
\text { Training in HR }\end{array}$ & 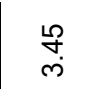 & 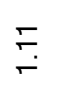 & $\stackrel{\mathscr{m}}{\tilde{m}}$ & ల్లా & $\stackrel{\sim}{\tilde{m}}$ & స̃ & $\stackrel{\text { ্ָ }}{0}$ & $\frac{10}{\circ}$ & $\frac{m}{5}$ & $\stackrel{\mathscr{N}}{0}$ & ஸ̊. & - & & & & \\
\hline $\begin{array}{l}\text { 20.Impact of } \\
\text { Professional } \\
\text { Organizations }\end{array}$ & $\stackrel{\substack{\infty \\
\sim}}{\sim}$ & $\stackrel{\infty}{\check{r}}$ & ల్ & $\frac{9}{\check{0}}$ & $\stackrel{0}{\frac{0}{0}}$ & 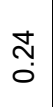 & $\stackrel{\mathscr{m}}{m}$ & $\stackrel{\text { N }}{0}$ & ¿̊. & ণָ & 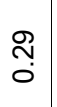 & חొ & $\begin{array}{l}\text { J } \\
0\end{array}$ & & & \\
\hline $\begin{array}{l}\text { 21.Impact of an Overall } \\
\text { HR Strategy }\end{array}$ & f) & $\stackrel{\circ}{\stackrel{20}{\leftarrow}}$ & 웅 & ले & ले & $\stackrel{\mathscr{N}}{0}$ & $\stackrel{\text { mे }}{\circ}$ & $\frac{\infty}{\check{0}}$ & ָุ & $\stackrel{\overbrace{}}{0}$ & 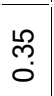 & @ & 萬 & กิ & & \\
\hline $\begin{array}{l}\text { 22.HR Staff's } \\
\text { Experiences in Other } \\
\text { Organizations }\end{array}$ & ণั & $\stackrel{m}{\stackrel{N}{\sim}}$ & $\begin{array}{l}\text { m్ } \\
\text { లె }\end{array}$ & ల్లి & $\frac{0}{5}$ & $\frac{0}{\circ}$ & 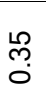 & $\stackrel{\text { N }}{0}$ & ¿̊. & $\stackrel{\frac{10}{5}}{0}$ & $\begin{array}{l}\stackrel{L}{N} \\
0\end{array}$ & 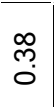 & mु. & $\underset{0}{\sharp}$ & f̊. & \\
\hline $\begin{array}{l}\text { 23/Knowledge and } \\
\text { Experience of HR } \\
\text { Department Staff }\end{array}$ & 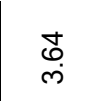 & $\stackrel{ }{ }$ & $\stackrel{\text { L }}{\leftarrow}$ & 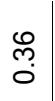 & 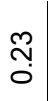 & $\stackrel{N}{0}$ & 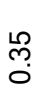 & N̦ & ণָ̣ & $\stackrel{N}{0}$ & $\stackrel{m}{m}$ & ợ & $\stackrel{\text { mे }}{\text { o }}$ & $\stackrel{\mathscr{Q}}{+}$ & חृ & P \\
\hline
\end{tabular}

Notes: $\mathrm{N}=217$ for all items, All correlations of 0.14 or greater are significant at $\mathrm{p}=0.05$, All correlations of 0.18 or greater are significant at $\mathrm{p}=0.01$ 
In order to investigate these relations further, an exploratory factor analysis (using varimax rotation) was conducted which identified factors with an eigenvalue greater than 1.0 , and which explained 59 percent of the variance. The first factor accounts for $33.023 \%$ of the variance, the second $9.172 \%$, the third $6.501 \%$, the fourth $5.938 \%$, and the fifth $4.735 \%$.

The first factor can be called as "characteristicsfactor" since it includes variables such as the industry and sector characteristics, size of the firm, structure of the firm, and history, traditions, and past practices. The second factor can be called as "strategy and know-how factor" because it includes variables such as the impact of an overall HR strategy, impact of HR theory/research, impact of education/training in HR, and knowledge and experience of HR department staff. The third factor can be called as "economy and technology factor" since it includes the impacts of changes in national and international economy, and changes in technology. The fourth factor can be called as "power and politics factor" because it includes the effects of issues of power and politics, and priorities of top and line managements. Finally, the fifth factor can be labeled as "regulation and union factor" since it includes the impacts of government regulations and actions of unions. A very interesting result of the factor analysis is that the impact of national culture and traditions is not included in any of the five factors.

On the basis of mean scores one can conclude that priorities of top management are the most important factors that influence HR practices. This may be due to the fact that top managements in the Turkish manufacturing firms are also the owners of the firms. In terms of the mean scores, other important variables are the organizational strategy, legislations and regulations, characteristics of the industry and sector, actions of corporate headquarter, and size of the organization. Although Kane and Palmer (1995) find actions of unions and HR staff's experience in other organizations as important factors, these two factors are not among the important factors affecting HR practices in the Turkish manufacturing industry. In Turkey, during the period starting with the military coup in 1980, the power of unions declined dramatically. As a result unions lost their overall influence in affecting firms' actions regarding their employees. The lower employee turnover may be the reason why HR staff's experience in other organizations does not emerge as an important factor. Although Turkey has implemented export oriented and open international economic policies since 1980, international economic changes do not appear as an important factor in influencing HR practices in the Turkish manufacturing industry. On the other hand, very same policies seem to lessen the importance of national culture and traditions.

To consider whether market orientation of the firm affects HR practices, firms were divided into two groups; national and international market oriented firms. On the basis of one-way analysis of variance (ANOVA), we find that the effect of HR staff's experience in other organizations on HR practices differ according to the market orientation of the firm $(p=0.002)$. In order to determine whether size 
affects the influences of various factors, firms were grouped according to the number of employees (less than 50, 50-99, 100-249, 250-499, and 500 and more). The ANOVA results show that the influences of 'changes in international economy' $(p=0.044)$, 'history/traditions/past practices' $(p=0.022)$, and 'priorities of top management' $(p=0,036)$ on HR practices change with the size of the firm. When we grouped the firms according to the existence/nonexistence of TQM strategy, ANOVA results indicate that existence of TQM strategy changes the influence of national culture/traditions $(p=0.022)$ and HR staff's experience in other organizations $(p=0.037)$ on HR practices. An important factor affecting HR practices is the existence of a clearly stated organizational mission. ANOVA results to test whether existence of organizational mission changes the influences of other factors demonstrate that the influences of national culture/traditions $(p=0.01)$ and power and politics $(p=0.017)$ become more significant when there is a written organizational mission. Finally, ANOVA results indicate that existence of an HR strategy leads to changes in the influences of technological changes $(p=0.027)$, national culture/traditions $(p=0.01)$, organizational mission $(p=0.012)$, organizational strategy $(p=0,003)$, activities of company headquarters $(p=0.016)$, size of the organization $(p=0.015)$, structure of the organization $(p=0.016), H R$ theory/research $(p=0.001)$, education/training in HR $(p=0.001)$, professional organizations $(p=0.016)$, overall HR strategy $(p=0.003)$, and knowledge and experience of HR department staff $(p=0.007)$. The main indication of ANOVA results is that existence of an HR strategy is the most influential control variable.

Table 3 is constructed by choosing respondents who rated the influence of the factors on HR practices as 4 or 5 and also rated influences of those factors on the sub fields as 4 or 5 . Table 3 reveals how different factors are seen as important in influencing specific areas of HR practices.

An interesting result of Table 3 is that the highest level of influence factors included falls on training and staff development. Also changes in national economy, sector characteristics, organizational mission and strategy, and size of the firm appear to have equally significant influences in all sub-areas of HR practices. 
Table 3: Type of Influence and Areas of Impact

\begin{tabular}{|c|c|c|c|c|c|c|}
\hline Influences on HR & 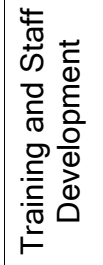 & 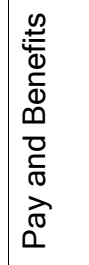 & 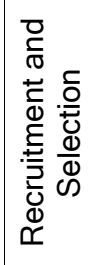 & 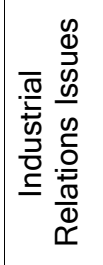 & 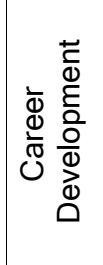 & 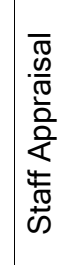 \\
\hline Changes in International Economy & 42 & 50 & 40 & 43 & 34 & 37 \\
\hline Changes in Technology & 79 & 58 & 58 & 59 & 45 & 53 \\
\hline Changes in National Economy & 67 & 81 & 73 & 71 & 65 & 57 \\
\hline National Culture Traditions & 38 & 26 & 25 & 27 & 34 & 30 \\
\hline Industry/Sector Characteristics & 67 & 65 & 72 & 62 & 59 & 53 \\
\hline Legislation/Regulation & 59 & 58 & 53 & 56 & 42 & 40 \\
\hline Actions of Unions & 33 & 44 & 42 & 35 & 34 & 30 \\
\hline Actions of Competitors & 51 & 49 & 52 & 37 & 42 & 41 \\
\hline Organizational Mission/Purpose & 83 & 60 & 70 & 61 & 59 & 66 \\
\hline Organizational Strategy/Objectives & 93 & 79 & 82 & 81 & 82 & 67 \\
\hline Actions of Corporate Headquarters & 76 & 69 & 73 & 71 & 55 & 64 \\
\hline Size of the Organization & 78 & 65 & 70 & 66 & 72 & 71 \\
\hline Structure of the Organization & 75 & 58 & 64 & 54 & 66 & 51 \\
\hline History/Traditions/Past Practices & 53 & 58 & 56 & 48 & 46 & 54 \\
\hline Priorities of Top Management & 82 & 73 & 77 & 66 & 72 & 72 \\
\hline Priorities of Line Management & 59 & 56 & 55 & 55 & 53 & 59 \\
\hline Issues of Power and Politics & 68 & 60 & 52 & 59 & 57 & 55 \\
\hline Impact of HR Theory/Research & 51 & 34 & 44 & 36 & 38 & 46 \\
\hline Impact of Education/Training in $\mathrm{HR}$ & 67 & 47 & 58 & 49 & 64 & 59 \\
\hline Impact of Professional Organizations & 31 & 23 & 26 & 20 & 24 & 25 \\
\hline Impact of an Overall HR Strategy & 60 & 53 & 58 & 45 & 48 & 50 \\
\hline $\begin{array}{l}\text { HR Staff's Experiences in Other } \\
\text { Organizations }\end{array}$ & 36 & 27 & 31 & 28 & 28 & 32 \\
\hline $\begin{array}{l}\text { Knowledge and Experience of HR } \\
\text { Department Staff }\end{array}$ & 76 & 70 & 74 & 67 & 77 & 82 \\
\hline
\end{tabular}




\section{CONCLUSION}

The literature review and survey analyses confirmed that HR practices (recruiting and selection, training and development, compensation and benefits, performance appraisal, career development, industrial relations) are related to internal and external factors. Our empirical results indicate that the most important internal factors affecting HR practices in the Turkish manufacturing industry are "priorities of top management", "organizational strategy", "actions of corporate headquarter", and "size of the organization". Important external factors, on the other hand, appear to be "legislations and regulations", and "characteristics of the industry and sector".

Of the factors affecting HR practices, the influence of "HR staff's experience in other organizations" differs according to the market orientation of the firm. An important finding of our empirical analysis is that the influences of "changes in international economy", "history/traditions/past practices", and "priorities of top management" change with the size of the firm. Our empirical results also show that existence of TQM strategy changes the influences of "national culture/traditions" and "HR staff's experience in other organizations". Furthermore, the influences of "national culture/traditions" and "power and politics" depend on the existence of a "clearly stated organizational mission". Most importantly, according to our empirical findings, the influences of all internal and external factors on HR practices in the Turkish manufacturing industry vary with existence/non-existence an overall HR strategy. That is, an overall HR strategy emerges as the most important control variable.

In sum, the main implication of our study is that both internal and external factors have significant influences on the HR practices in the Turkish manufacturing industry. From a theoretical perspective, therefore, we can argue that different HR approaches are not mutually exclusive, but in fact they complete each other in explaining factors affecting HR practices.

\section{REFERENCES}

ALAS, R., KAARELSON, T. and NIGLAS, K. (2008), "Human Resource Management in Cultural Context: Empirical Study of 11 Countries", EBS Review, 24 (1): 49-63.

BAIRD, L. and MESHOULAM, I. (1988), "Managing To Fits of Strategic Human Resource Management", Academy Of Management Review, 13 (1):116-128.

BECKER, B.A., HUSELID, M.A. and ULRICH, D. (2001), the HR Scorecard: Linking People, Strategy, and Performance, Harvard Business School Press, Boston. 
CHANDRAKUMARA, A. and SPARROW, P. (2004), "Work Orientation as an Element of National Culture and Its Impact on HRM Policy-PracticeDesign Choices", International Journal of Manpower, 25 (6): 564-589.

CHANG, W-J. A. and HUANG, T.C. (2005), "Relationship between Strategic Human Resource Management and Firm Performance", International Journal of Manpower, 26 (5): 434-449.

CROW, S., HARTMAN, S., KOEN, C. and EPPS, P.V. (1995), "A Constituency Theory Perspective of Human Resource Effectiveness", Employee Relations, 17 (1): $38-50$.

DARMER, P. (2000), "The Subjectivity of Management", Journal of Organizational Change Management, 13 (4): 334-351.

DELERY, J.E. and DOTY, D.H. (1996), "Modes of Theorizing in Strategic Human Resource Management: Test of Universalistic, Contingency, And Configurational Performance Predictions", Academy of Management Journal, 39 (4): 802-835.

DYER, L, (1984), "Studying Human Resource Strategy: An Approach and an Agenda", Industrial Relations, .23 (2): 156-169.

GARAVAN, T. N., WILSON, J. P., CROSS, C. and CARBERY R. (2008), "Mapping the Context and Practice of Training, Development and HRD in European Call Centers", Journal of European Industrial Training, 32 (8/9): 612728.

GARVIN, D.A. (1986), "What Does Product Quality Really Mean?" Sloan Management Review, 25-43.

GAUTAM, D. K. and DAVIS, A. J. (2007), "Integration and Devolvement of Human Resource Practices in Nepal", Employee Relations, 29 (6): 711-726.

GHOBADIAN, A. and GALLEAR, D. (1997), "TQM and Organization Size", International Journal of Operations and Production Management, 17: 121-163.

GONZALEZ, S. M. and TACORONTE, D. V. (2006), "Is There More Than One Way to Manage Human Resources in Companies?", Personnel Review, 35 (1): 29-50.

GOWLER, D, and LEGGE, K. (1986), "Personnel and Paradigms: Four Perspectives On The Future", Industrial Relations Journal, 17 (3): 225-235.

GRUNDY, T. (1997), "Human Resource Management-A Strategic Approach", Long Range Planning, 30 (4): 507-517. 
HUDSON, M., SMART, A. AND BOURNE, M. (2001), "Theory and Practice in SME Performance Management System", International Journal of Operations and Productions Management, 21: 1096-1115.

JACKSON, S.E., SCHULER, R.S. and RIVERO, J.C. (1989), "Organizational Characteristics As Predictors Of Personnel Practices", Personnel Psychology, 42 (4): 727-786.

JACOBY, S.M. (1983), "Industrial Labor Mobility In Historical Perspective", Industrial Relations, 22: 261-282.

KAMOCHE, K. (1991), "Human Resource Management: A Multiparadigmatic Analysis", Personnel Review, 20 (4): 3-14.

KANE, B. and PALMER, I. (1995), "Strategic HRM Or Managing The Employment Relationship?" International Journal of Manpower, 16 (5): 6-21.

KAYNAK, T., ADAL, Z. and ATAAY, İ. (1998), Human Resource Management, Istanbul: Donence Basin ve Yayin Hizmetleri, Turkey.

KOCHAN, T.A., MC KERSIE, R.B. and CAPELLI, P. (1984), "Strategic Choice and Industrial Relations Theory", Industrial Relations, 23: 16-39.

KOZAN, K. (1999), "The Influence of Intra-Cultural Value Differences on Conflict Management Practices", International Journal of Conflict Management, 10 (3): 249-268.

LENGNICK-HALL C.A. and LENGNICK-HALL M.L. (1988), "Strategic Human Resource Management: A Review Of The Literature And A Proposed Typology", Academy of Management Review, 13 (3): 454-470.

MCPHERSON, M. (2008), "HRM Practices and Systems within South-Asian Small Business", International Journal of Entrepreneurial Behaviour \& Research, 14 (6): 414-439.

MEYER, N. (1980), "Organizational Structure as Signaling", Pacific Sociological Review, 22: 481-500.

MILES, R.E. and SNOW, C.C. (1984), "Designing Strategic Human Resource Systems", Organization Dynamics, 13: 36-52.

MILKOVICH, G.T. and BOUDREAU, J.W. (1991), Human Resource Management, USA: Richard D. Irwin, Inc.

NARASIMHA, S. (2000), "Organizational Knowledge, Human Resource Management and Sustained Competitive Advantage: Toward A Framework", Competitiveness Review, 10 (1): 123-136. 
OKPARA, J.O. and WYNN, P. (2008), "Human Resource Management Practices in a Transition Economy", Management Research News, 31 (1): 5776.

ONDRACK, D.A. and NININGER, J.R. (1984), "Human Resource Strategies-The Corporate Perspective", Business Quarterly, 49 (4): 101-109.

OSTERMAN, P. (1987), "Choice of Employment Systems in Internal Labor Markets", Industrial Relations, 26: 46-67.

PARDO, M. and FUENTES, C.M. (2003), "Resistance to Change: A Literature Review and Empirical Study", Management Decision, 41 (2): 148-155.

PECK, S.R. (1994), "Exploring the Link between Organizational Strategy and the Employment Relationship: The Role of Human Resource Policies", Journal of Management Studies, 31 (5): 715-735.

PFEFFER, J. (1994), Competitive Advantage through People: Unleashing the Power of the Workforce, Boston: Harvard Business School Press.

PFEFFER, J. and COHEN, Y. (1984), "Determinants of Internal Labor Markets In Organizations", Administrative Science Quarterly, 29: 550-572.

POOLE, M. and JENKINS G. (1996). "Competitiveness and Human Resource Management Policies", Journal of General Management, .22 (2): 1-19.

POOLE, M. and JENKINS, G. (1997), "Responsibilities for Human Resource Management Practices in the Modern Enterprise", Personnel Review, 26 (5): 333-356.

POWER, D. (2004), "The Comparative Importance of Human Resource Management Practices in the Context of Business to Business (B2B) Electronic Commerce", Information Technology \& People, 17 (4): 380-406.

SATOW, T. and WANG, Z.M., (1994), "Cultural and Organizational Factors In Human Resource Management In China and Japan", Journal of Managerial Psychology, 9 (4): 3-11.

SCHULER, R.S. (1992), "Strategic Human Resource Management: Linking People with the Needs of the Business", Organizational Dynamics, 20: 19-32.

SPENCER, L.M. and SEPENCER, S.M. (1993), Competence at Work: Models for Superior Performance, John Willey.

SULLY, T., BEECHKER, S. and NAPIER, N. (1996), "Toward an Integrative Model of Strategic International Human Resource Management", Academy of Management Review, 21 (4): 959-985. 
TERPSTRA, D.E. and ROZELL, E.J. (1993), "The Relationship of Staffing Practices to Organizational Level Measures of Performance", Personnel Psychology, .46: 27-48.

TICHY, N.,FOMBRUN, C.J. and DEVANNA, M.A. (1982), "Strategic Human Resource Management", Sloan Management Review, 23 (2): 47-64.

TOLBERT, P. and ZUCKER, L.G. (1983), "Institutional Sources of Change In The Formal Structure of Organizations", Administrative Science Quarterly, 28: 22-39.

TOMER, J. (1995). "Strategy and Structure in the Human Firm: Beyond Hierarchy, Toward Flexibility and Integration", Journal of Socio-Economics, 24 (3): 411-432.

TSUI, A.S., and MILKOVICH, G.T. (1987), "Personnel Department Activities: Constituency Perspectives and Preferences", Personnel Psychology, 40: 519537.

WANG, D-S and SHYU, C-L (2008), "Will the Strategic Fit between Business and HRM Strategy Influence HRM Effectiveness and Organizational Performance“, International Journal of Manpower, 29 (2): 92-110.

WASTI, S.A. (1998), "Cultural Barriers in the Transferability of Japanese and American Human Resource Practices to Developing Countries: The Turkish Case", the International Journal of Human Resource Management, 9 (4): 608632.

WATSON, S. and GREEN, N.D. (1996), "Implementing Cultural Change through Human Resources: The Elusive Organization Alchemy?" International Journal of Contemporary Hospitality Management, 8 (2): 25-30.

WELCH, D. (1994), "Determinants of International Human Resource Management Approaches and Activities: A Suggested Framework", Journal of Management Studies, 31(2): 139-161.

WONG, M. M. L. (1997), "Human Resource Policies in Two Japanese Retail Stores in Hong Kong", International Journal of Manpower, 18 (3): 281-295.

YEGANEH, H. and SU, Z. (2008), "An Examination of Human Resource Management Practices in Iranian Public Sector", Personnel Review, 37 (2): 203221. 